\title{
GEOGRAPHIC ACCUMULATION OF CREUTZFELDT- JAKOB DISEASE IN SLOVAKIA - ENVIRONMENTAL METAL IMBALANCE AS A POSSIBLE COFACTOR
}

\author{
Dana Slivarichová1, Eva Mitrová1, Monika Ursínyová2, Iveta Uhnáková2, Silvia Koščová1, Ladislava Wsólová3 \\ ${ }^{1}$ Department of Prion Diseases, Slovak Medical University, Bratislava, Slovak Republic \\ ${ }^{2}$ Laboratory of Toxic and Essential Elements, Slovak Medical University, Bratislava, Slovak Republic \\ ${ }^{3}$ Department of Biostatistical Analysis, Slovak Medical University, Bratislava, Slovak Republic
}

\begin{abstract}
SUMMARY
Slovakia is characterised by an unusually high number of patients affected by genetic Creutzfeldt-Jakob disease (CJD) with E200K mutation at the PRNP gene. Penetrance of the mutation is incomplete (59\%). Therefore, for the onset of the clinical manifestation, an influence of other endo- or exogenous factors could not be excluded. Experimental data suggest that copper and manganese levels may play an important role in the pathogenesis of prion diseases. The highest number of Slovak genetic CJD patients originates from Orava - the northern region of central Slovakia. Manganese is a dominant pollutant in Orava. The objective of this study was to clarify a possible exogenous influence of environmental $\mathrm{Mn} / \mathrm{Cu}$ imbalance on the CJD clustering. Mn and Cu levels were analysed in the brain tissue of genetic CJD cases (from Orava and from control regions of Slovakia), as well as of sporadic CJD patients and controls. Analyses demonstrate i) significantly higher Mn level in focally accumulated, "clustering" genetic CJD cases in comparison to all other groups, ii) Cu status differences between compared groups were without statistical significance; decreased concentrations were found in genetic cases from extrafocal genetic CJD areas, iii) Mn/Cu ratios were increased in all CJD groups in comparison to controls. Metal ratios in clustering gCJD cases were significantly higher in comparison to sporadic cases and also to controls, but not to the extrafocal genetic CJD subgroup. These results indicate that more important than increasing Mn level in pathogenesis of CJD appears to be the role of the $\mathrm{Mn} / \mathrm{Cu}$ imbalance in the CNS. The imbalance observed in the cluster of genetic CJD cases is probably a result of both: the excessive environmental $\mathrm{Mn}$ level and the disturbance of $\mathrm{Mn} / \mathrm{Cu}$ ratios in the Orava region. Presented findings indicate an environmental $\mathrm{Mn} / \mathrm{Cu}$ imbalance as a possible exogenous CJD risk co-factor which may, in coincidence with endogenous (genetic) CJD risk, contribute to the focal accumulation (cluster) of genetic CJD in Slovakia.
\end{abstract}

Key words: manganese, copper, metal imbalance, Creutzfeldt-Jakob disease, cluster

Address for correspondence: D. Slivarichová, Department of Prion Diseases, Slovak Medical University, Limbová 12, 83303 Bratislava, Slovak Republic. E-mail: dana.slivarichova@szu.sk

\section{INTRODUCTION}

Scrapie, bovine spongiform encephalopathy (BSE), chronic wasting disease (CWD) of animals and Creutzfeldt-Jakob disease (CJD) affecting humans belong to the group of transmissible spongiform encephalopaties (TSE) - "prion diseases" - a group of fatal, untreatable and transmissible diseases of the central nervous system (CNS).

The presence of pathological prion protein (PrPsc) in an affected individual is the common feature of prion diseases $(1-4)$. Prion is currently believed to be the main, if not the only, pathological infectious agent of TSE.

The precursor of the pathological prion is cellular prion protein PrPc. PrPc is a glycoprotein expressed on the surface of many cell types, mainly in neurones (5). It is known, that PrPc -deficient mice show a phenotype indicating that they are more sensitive to various kinds of stress. These data imply that PrPc has an important role in protecting cells from environmental assaults. Moreover, there is an evidence that $\mathrm{PrPc}$ expression increases when the brain is stressed by oxidative damage (6).
Brown and his colleagues (7) have shown that full-length PrP binds up to four copper atoms to the octameric repeat region. PrP refolded with copper was demonstrated to have an antioxidant activity like that of superoxide dismutase (8). Minimum number of copper ions required for superoxide dismutase activity is two, but the molecule shows increased activity when the further two atoms of copper bind (9), probably due to increased order in the molecule (10).

It is known that copper-binding proteins can often bind other divalent cations under certain circumstances. Brown (9) has demonstrated that manganese is incorporated into native PrP from cells cultured with manganese in the medium. Therefore, it seems to be possible that manganese can be incorporated into to PrPc in vivo. The central event in the pathogenesis of the prion diseases is the conversion of $\mathrm{PrPc}$ to an abnormal isoform that is proteinase resistant $(11,12)$ and possibly the infectious agent itself $(\mathrm{PrPsc})$ (4). It appears that PrP is less stable on binding manganese and quickly converts to a misfolded form, which is likewise PrPsc proteinase resistant $(8)$ and leads to fibril formation $(13,14)$.

The most important human TSE is Creutzfeldt-Jakob disease (CJD), a rare disorder, with annual occurence 1.5 case per mil- 
lion world-wide. The mean survival time of CJD patients is four months, and most of the patients die within the first year after the onset of clinical symptoms. CJD can occur in one of three forms: sporadic (sCJD), which is of unknown origin; genetic (gCJD), related to disease-specific mutations in the prion protein gene $(P R N P)$; and iatrogenic (iCJD), acquired due to exposure to prion-contamined equipment or tissue.

The prospective study of CJD in Slovakia started in 1975. Slovakia is characterised by an exceptionally high number of gCJD with E200K mutation at $P R N P$ gene. This CJD-specific mutation is linked to the development of the disease and significantly reduces its clinical duration. It has also been detected in healthy blood relatives of gCJD patients. Penetrance of mutation is incomplete, only $59 \%$ of carriers developed disease throughout their life (15). Therefore, an interaction of other endo- or exogenous factors in the development of clinical manifestation could not be excluded.

Many previous investigations suggested that manganese and copper play an important role in the pathogenesis of TSEs. Buchl et al. (16) presented the hypothesis that trace metal isotopes can be used to examine processes leading to brain damage and disease and pathways by which metals are transported through the body. Animal studies have demonstrated that application of a manganese chelation therapy extends survival in a scrapie mouse model (17) and that scrapie inoculated mice show elevation of manganese and decreased level of copper in the brain (18). Elevation of manganese in the brain was previously identified only in workers exposed to high concentrations of manganese in the industrial and in the environmental settings. These workers developed "manganese madness" - a Parkinson's like syndrome (19-21).

Most Slovak gCJD patients were born in Orava, the north CJD clustering region (22). Manganese is a dominant pollutant in this region, since 1952 OFZ joint-stock company with ferroalloys production has been operating there at two plants (Istebné and Široká). Istebné plant, established in 1952, produces ferroalloys based on chromium, and Široká plant, established in 1965 , produces ferroalloys based on silicon and manganese. The environmental pollution with manganese in the Orava region was very high, especially in the past, due to the described production.

Pollution control measures, but mainly the reduction of economic activity (after Velvet Revolution in 1989), resulted in decreased emissions of Mn, but Mn emissions in CJD cluster region are still higher than in other Slovak regions.

The pathogenesis of transmissible spongiform encephalopathies is still not completely elucidated, but an increasing number of data indicates that an important role may have endo- and exogenous factors.

The aim of this study was to investigate the influence of manganese/copper environmental imbalance as a possible exogenous co-factor on the development of the clinical manifestation of gCJD and to confirm/exclude its participation in the focal accumulation (clustering) of gCJD patients in Slovakia.

\section{MATERIALS AND METHODS}

\section{Tissue Samples}

18 patients classified as gCJD were divided into 2 groups following their geographical origin. The first genetic group represented patients from the Orava region, the second genetic group included patients from other parts of Slovakia. 18 sporadic CJD cases were from the whole country. Occurrence of any other pathogenic mutation of $P R N P$ gene was excluded by a sequence analysis of every definite CJD patient without the mutation E200K. The control group consisted of 18 patients with suspected CJD referred to the NRC PD in whom the CJD was excluded. Their final diagnoses are not known. The consent to use this material for research had been obtained.

For metal determination, frontal cortex tissues have been chosen, since excision from the frontal lobe was most regularly received in autoptic material by Slovak National Reference Center for prion diseases (NRC PD) from pathological departments. All 54 human brain autopsy tissues and blood samples were from the tissue bank of the NRC PD. Samples were only identified by the notification number, and all analyses were undertaken blind to the patient's diagnostic category.

\section{PRNP Analysis}

As a routine procedure we performed restriction fragment polymorphism analysis using restriction enzymes specific to the PRNP gene polymorphism at codon 200 in all patients referred to NRC PD irrespective of clinical clasification and positive family history for TSE, dementia, or other neurological disorders. Genomic DNA was extracted from whole blood or frozen brain by phenol extraction. The PRNP open reading frame was amplified by the PCR with the primers (PRNP FOR 5"- TCAACATAAATATGGGACTCTCTGACG -3“ and PRNP REV 5“ - GCCTATCCGGGACAAAGAGAAGA- 3") in an automated Peltier thermal cycler 200 (MJ Research). PCR was run through 35 cycles at $94^{\circ} \mathrm{C}$ for 90 seconds, at $62^{\circ} \mathrm{C}$ for 90 seconds, at $72^{\circ} \mathrm{C}$ for 3 minutes, plus a final step at $72^{\circ} \mathrm{C}$ for 5 minutes. PCR product was detected on $1.5 \%$ agarose gel and restricted with restriction enzyme specific to the gene mutation at codon 200 (enzyme BsmAI, New England Biolabs, restriction was run at $55^{\circ} \mathrm{C}$ for 4 hours). Restriction fragments were detected on $1.5 \%$ agarose gel by ChemiDoc detection system (BioRad).

\section{Determination of $\mathrm{Mn}$ a $\mathrm{Cu}$}

Frontal cortex tissues $(2.5 \mathrm{~g})$ were wet mineralized using the mixture of $3.5 \mathrm{ml} 65 \% \mathrm{HNO}_{3}$ Suprapure MERCK, and $1.5 \mathrm{ml} \mathrm{H}_{2} \mathrm{O}_{2}$ Suprapure, MERCK by a highpressure microwave system MLS 1200 Mega, MILESTONE. Mineralized samples were made up to $25 \mathrm{ml}$ with bidistilled water. The determination of manganese and copper was done by flame atomic absorption spectrometry using Philips 9400X spectrophotometer. During the analytical work, together with each series of samples, always at least one blank and one reference material were run and analysed for the respective elements. The method of calibration curve was used for calibration and quantification. For validation of the results, certified reference material - SRM Bovine liver 1577b was analyzed. Determination of copper isotopes $\left({ }^{63} \mathrm{Cu}\right.$ and $\left.{ }^{65} \mathrm{Cu}\right)$ was realised by the inductively coupled plasma mass spectrometry using XSeries 2 .

To express the state of metal balance in the CNS of patients, besides metal's concentration we focused also on their correlative ratio $\mathrm{Mn} / \mathrm{Cu}$. With increasing metal rate $\mathrm{Mn} / \mathrm{Cu}$ in brain tissue of CJD cases in comparison to controls, the metal imbalance accrues. 
For statistical evaluation of the results, Kruskal-Wallis and Ulmenyi tests were used.

\section{RESULTS}

Detection of mutation and polymorphism in the PRNP gene. On the base of PRNP analysis of neurohistopathologically confirmed CJD, 18 cases were classified as gCJD (Table 1), with glutamate to lysine change at codon 200 (E200K).

Brain metal levels. 54 samples of brain tissue, 18 genetic CJD (9 genetic CJD from CJD cluster - Table 1, 9 genetic CJD cases from other parts of Slovakia - Table 2), 18 sporadic CJD (Table 3 ) and 18 controls (Table 4) were examined.

Manganese (Fig. 1). Comparative analysis of manganese levels in the brain tissue between tested groups indicate significantly higher Mn level in gCJD group from Orava in comparison to controls $(\mathrm{p}<0.001)$, to gCJD group from extrafocal parts of Slovakia $(p=0.002)$, to $\operatorname{sCD}(p=0.009)$. Mn level in $\mathrm{sCJD}$ was higer than in the control group, the difference was not statistically significant. In the extrafocal gCJD cases the manganese level slightly decreased comparing to controls.

Copper (Fig. 2). The highest $\mathrm{Cu}$ level was in genetic CJD from the Orava region. $\mathrm{Cu}$ levels in genetic CJD from other parts of Slovakia and in sporadic CJD were decreased in comparison to controls. Differences between tested groups were not significant.

$\mathrm{Mn} / \mathrm{Cu}$ ratio (Fig. 3). Metal ratio indicating $\mathrm{Mn} / \mathrm{Cu}$ imbalance was increased in all tested CJD groups (genetic CJD from Orava, genetic CJD out of cluster, sporadic CJD) in comparison with controls. $\mathrm{Mn} / \mathrm{Cu}$ ratio was in genetic CJD from Orava significantly higher than in controls $(\mathrm{p}=0.002)$ and higher than in sporadic CJD $(p=0.027)$. The metal ratio between gCJD groups shows no statistically significant difference.

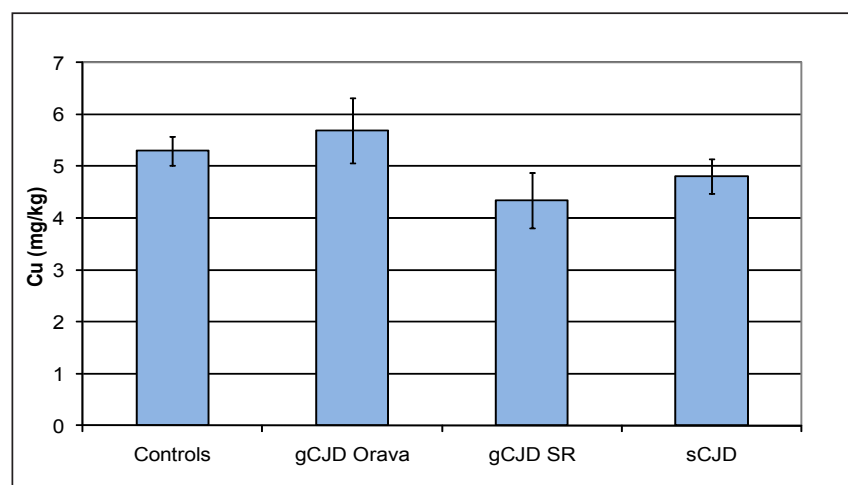

Fig. 2. Copper concentration. Geographic accumulation of CJD in Slovakia.

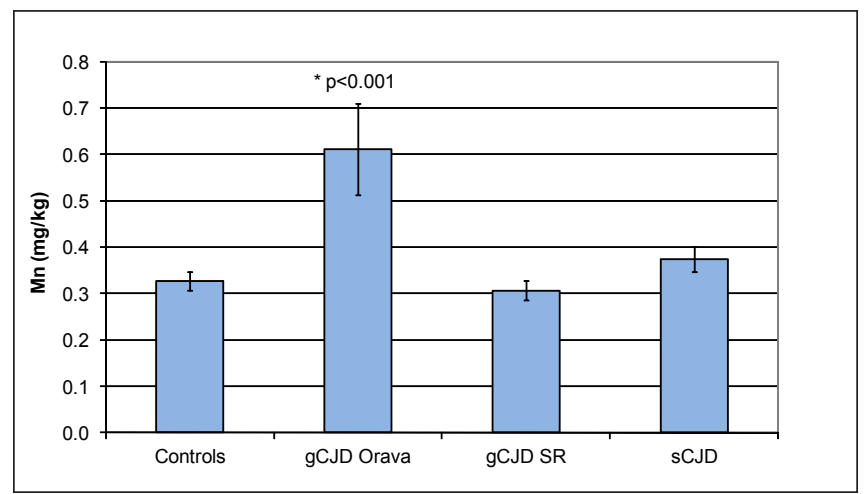

Fig. 1. Manganese concentration. Georaphic accumulation of CJD in Slovakia.

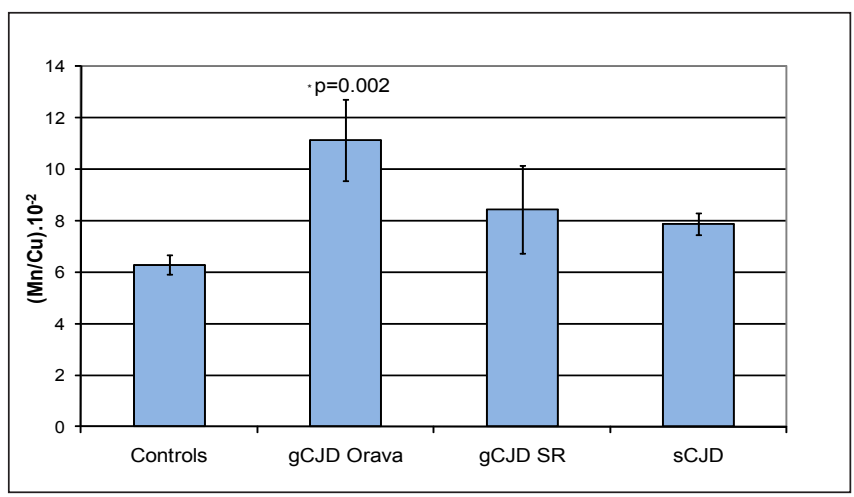

Fig. 3. $\mathrm{Mn} / \mathrm{Cu}$ ratio. Geographic accumulation of CJD in Slovakia.

Table 1. Metal concentrations in genetic CJD group from Orava region

\begin{tabular}{|c|c|c|c|c|c|}
\hline Case No. & Sample & Region & $\begin{array}{c}\mathrm{Mn} \\
{\left[\mathrm{mg}^{2} \mathrm{~kg}^{-1}\right]}\end{array}$ & $\begin{array}{c}\mathrm{Cu} \\
{\left[\mathrm{mg}^{2} \mathrm{~kg}^{-1}\right]}\end{array}$ & $(\mathrm{Mn} / \mathrm{Cu}) \cdot 10^{-2}$ \\
\hline 1 & 8303 & Orava & 1.01 & 8.80 & 11.47 \\
\hline 2 & 8016 & Orava & 0.39 & 4.40 & 8.86 \\
\hline 3 & 8154 & Orava & 0.42 & 5.00 & 8.40 \\
\hline 4 & 8239 & Orava & 0.65 & 3.50 & 18.57 \\
\hline 5 & 8468 & Orava & 0.41 & 7.60 & 5.39 \\
\hline 6 & 7265 & Orava & 1.18 & 6.10 & 19.34 \\
\hline 7 & 8353 & Orava & 0.42 & 4.70 & 8.94 \\
\hline 8 & 8389 & Orava & 0.63 & 7.40 & 8.51 \\
\hline 9 & 8668 & Orava & 0.39 & 3.70 & 10.50 \\
\hline \multicolumn{3}{|l|}{ Average } & 0.61 & 5.68 & 11.10 \\
\hline
\end{tabular}


Table 2. Metal concentrations in genetic CJD group from other parts of Slovakia

\begin{tabular}{|c|c|c|c|c|c|}
\hline Case No. & Sample & Region & $\begin{array}{c}\mathrm{Mn} \\
{\left[\mathrm{mg}^{\left.-\mathrm{kg}^{-1}\right]}\right.}\end{array}$ & $\begin{array}{c}\mathrm{Cu} \\
{\left[\mathrm{mg}^{\left.-k^{-1}\right]}\right.}\end{array}$ & $(\mathrm{Mn} / \mathrm{Cu}) \cdot 10^{-2}$ \\
\hline 1 & 8644 & Nitra & 0.25 & 4.80 & 5.20 \\
\hline 2 & 8448 & Piešt’any & 0.28 & 5.80 & 4.82 \\
\hline 3 & 8265 & Skalica & 0.32 & 1.50 & 21.33 \\
\hline 4 & 8879 & Nitra & 0.22 & 2.20 & 10.00 \\
\hline 5 & 8938 & Nitra & 0.34 & 4.60 & 7.39 \\
\hline 6 & 8980 & Kežmarok & 0.30 & 4.90 & 6.12 \\
\hline 7 & 9102 & Košice & 0.34 & 4.00 & 8.50 \\
\hline 8 & 9087 & Rožkovany & 0.44 & 6.70 & 6.60 \\
\hline 9 & 9017 & Zlatá Idka & 0.27 & 4.60 & 5.80 \\
\hline \multicolumn{3}{|l|}{ Average } & 0.31 & 4.30 & 8.42 \\
\hline
\end{tabular}

Table 3. Metal concentrations in sporadic CJD group

\begin{tabular}{|c|c|c|c|c|c|}
\hline Case No. & Sample & Region & $\underset{\left[\mathrm{mg}^{2} \mathrm{~kg}^{-1}\right]}{\mathrm{Mn}}$ & $\begin{array}{c}\mathrm{Cu} \\
{\left[\mathrm{mg}^{\left.-k^{-1}\right]}\right.}\end{array}$ & $(\mathrm{Mn} / \mathrm{Cu}) \cdot 10^{-2}$ \\
\hline 1 & 8497 & Levoča & 0.25 & 3.6 & 6.94 \\
\hline 2 & 8319 & Spišské Podhradie & 0.40 & 4.6 & 8.69 \\
\hline 3 & 8526 & Orava & 0.52 & 4.9 & 10.61 \\
\hline 4 & 8260 & Banská Bystrica & 0.48 & 6.2 & 7.74 \\
\hline 5 & 8553 & Galanta & 0.31 & 4.8 & 6.45 \\
\hline 6 & 8364 & Bratislava & 0.24 & 2.4 & 10.00 \\
\hline 7 & 8473 & Považská Bystrica & 0.36 & 6.6 & 5.45 \\
\hline 8 & 8683 & Nitra & 0.38 & 4.8 & 7.91 \\
\hline 9 & 8951 & Liptovský Mikuláš & 0.51 & 5.5 & 9.27 \\
\hline 10 & 8831 & Poprad & 0.39 & 4.4 & 7.73 \\
\hline 11 & 8926 & Prešov & 0.41 & 3.3 & 12.42 \\
\hline 12 & 8806 & Banská Bystrica & 0.57 & 7.6 & 7.50 \\
\hline 13 & 8747 & Nitra & 0.27 & 4.4 & 6.14 \\
\hline 14 & 8900 & Bratislava & 0.55 & 7.1 & 7.74 \\
\hline 15 & 9052 & - & 0.33 & 4.2 & 7.85 \\
\hline 16 & 9066 & - & 0.24 & 5.0 & 4.80 \\
\hline 17 & 9076 & - & 0.21 & 3.0 & 7.00 \\
\hline 18 & 9099 & - & 0.30 & 4.1 & 7.30 \\
\hline \multicolumn{3}{|l|}{ Average } & 0.37 & 4.8 & 7.86 \\
\hline
\end{tabular}

\section{DISCUSION}

The central event in the pathogenesis of prion diseases is the conversion of cellular prion protein to an abnormal protease resistant isoform - prion. An increasing number of experimental data in the literature suggest that copper and manganese play an important role in the function and stability of cellular prion protein. $\mathrm{PrPc}$ binds copper and this metaloprotein has an antioxidant activity, but under certain circumstances manganese can replace copper what leads to changes in a secondary structure $(9,14)$. Moreover binding of manganese to the prion protein is able to convert the protein into a form that is able to initiate seeded polymerization of the protein (13). Changes in the copper and manganese levels, as well as a reduction in copper binding to the prion protein and a proportional decrease in antioxidant activity were observed in the brain of experimentally infected animals (18) and in human CJD affected brain (23).

The occurence of the most important human prion disorder Creutzfeldt-Jakob disease - in Slovakia shows certain specific features comparing to the other countries. While world-wide, the most frequent CJD is the sporadic form (80\%), in Slovakia, as much as $65 \%$ of all CJD cases is represented by genetic cases, with 
Table 4. Metal concentrations in control group

\begin{tabular}{|c|c|c|c|c|c|}
\hline Case No. & Sample & Region & $\begin{array}{c}\mathrm{Mn} \\
{\left[\mathrm{mg}^{\left.-k^{-1}\right]}\right.}\end{array}$ & $\begin{array}{c}\mathrm{Cu} \\
{\left[\mathrm{mg}^{\left.-\mathrm{kg}^{-1}\right]}\right.}\end{array}$ & $(\mathrm{Mn} / \mathrm{Cu}) \cdot 10^{-2}$ \\
\hline 1 & 8202 & Poprad & 0.26 & 4.6 & 5.65 \\
\hline 2 & 8397 & Martin & 0.36 & 4.9 & 7.30 \\
\hline 3 & 8120 & Bratislava & 0.37 & 4.5 & 8.22 \\
\hline 4 & N6 & Bratislava & 0.24 & 4.4 & 5.40 \\
\hline 5 & N5 & Bratislava & 0.22 & 4.6 & 4.78 \\
\hline 6 & N4 & Bratislava & 0.24 & 5.5 & 4.36 \\
\hline 7 & 8869 & Brezno & 0.32 & 8.0 & 4.00 \\
\hline 8 & 8821 & Košice & 0.29 & 4.5 & 6.44 \\
\hline 9 & 8588 & Žilina & 0.56 & 7.1 & 7.89 \\
\hline 10 & 8992 & Vel'ká Mača & 0.37 & 6.3 & 5.87 \\
\hline 11 & 9091 & Trnava & 0.24 & 4.7 & 5.10 \\
\hline 12 & 9009 & Šal'a & 0.41 & 7.8 & 5.25 \\
\hline 13 & 9032 & Košice & 0.33 & 4.4 & 7.50 \\
\hline 14 & 9089 & Bratislava & 0.28 & 4.9 & 5.70 \\
\hline 15 & 9098 & Prešov & 0.29 & 5.1 & 5.60 \\
\hline 16 & 9095 & Tvrdošín & 0.42 & 4.4 & 9.50 \\
\hline 17 & 9105 & Bratislava & 0.3 & 5.4 & 5.50 \\
\hline 18 & 8271 & Ružomberok & 0.38 & 4.2 & 9.04 \\
\hline \multicolumn{3}{|l|}{ Average } & 0.33 & 5.3 & 6.28 \\
\hline
\end{tabular}

E200K mutation in PRNP gene with incomplete - 59\% penetrance (15). There are two focal, rural accumulations of genetic CJD patients in the central Slovakia, more concentrated one is in the Orava region (northern part of central Slovakia). The environment of this region is contaminated by manganese and other metals from OFZ joint-stock company with ferroalloys production. OFZ was established in 1952, and in the past it covered metallurgy industry with alloys products within all Czechoslovakia. Emissions of manganese in Slovakia in the period of 1990-2002 show a decreasing tendency.

In Široká, dust deposition of Mn decreased from 4,607.9 to $1,513.3 \mu \mathrm{g} . \mathrm{m}^{-2}$ per day in the course of $1985-1989$, whereas dust deposition of $\mathrm{Mn}$ in other locations of Slovakia was in the range of 51.1-165.9 $\mu \mathrm{g} . \mathrm{m}^{-2}$ per day in the same period (24). In the gCJD clustering region - Orava, the increased ambient air Mn concentration has been determined (25) as well as increased Mn concentration in soil, vegetation (26), hair of children (27) and food - bread, apple, honey (28).

Despite of the decreasing values, Mn contamination in Orava persists, as following studies indicate:

- 12.9 mg.kg of manganese was detected in hair of children in 1995; maximal limit defined by WHO is 4 mg.kg (27).

- Vegetation in the Orava region showed 2.5 times more manganese than vegetation in other Slovak regions (26).

- Soil and food (apple, bread and honey) from Orava had significantly higher Mn concentration than from the rest of the country (28).

It is interesting that studies focused on workers exposed to high concentrations of manganese in the industrial and in the environmental settings (with "manganese madness") indicate the following symptoms, common with prion diseases $(29,30)$ :

- depression, insomnia, ataxia;

- amyloid fibrils in the CNS $(31,32)$;

- high Mn concentration in astrocytes (33).

E200K is an important endogenous risk factor for the development of gCJD. Nevertheless, considering its incomplete penetrance as well as studies on exogenous risk factors in Orava, a coincidence and participation of both, endo- and exogenous risk appears to play a role in geographical accumulation of gCJD cases $(21,34)$. The aim of our study was to investigate a possible influence of environmental manganese/copper imbalance as an exogenous co-factor in the development of clinical manifestation of gCJD and to confirm/exclude its role in the focal, geographical cluster of gCJD in Slovakia.

The current work provides results of metal levels determination in brain tissue of 54 individuals affected by gCJD, sCJD and the control group. To verify a causal role of the investigated environmental metal disbalance in the Oravian cluster of gCJD, the analysed gCJD patients have been divided into 2 groups, according to their geographical origin (Orava and the rest of Slovakia). Patients included into Orava group have been living in this region and also deceased there, patients from the rest of Slovakia never spent longer period (months, years) in Orava.

Presented results of our comparative analysis focused on metal levels indicate that Mn concentrations in gCJD from Orava are significantly higher than in other tested groups: (gCJD Orava $>$ controls, $\mathrm{p}<0.001$; gCJD Orava $>$ gCJD other parts of Slovakia, $\mathrm{p}=0.002$; gCJD Orava $>\mathrm{sCJD}, \mathrm{p}=0.009$ ). Mn level in $\mathrm{sCJD}$ was 
higher in comparison to controls, but the difference was not of statistical significance, Mn level in extrafocal gCJD was even decreased when compared to controls. Manganese elevation in gCJD group from Orava is probably a consequence of environmental manganese contamination in that region. While the respiratory and gastrointestinal tracts are the primary means of Mn entry into the body, most Mn toxicities in humans are associated with inhalation (35), primarily because inhaled $\mathrm{Mn}$ is more likely to reach the CNS before hepatic clearance (36). Legleiter with colleagues (37) supported this assumption, since their data indicate that high $\mathrm{Mn}$ diets do not lead to increased $\mathrm{Mn}$ brain concentration. Our results achieved in gCJD represent the first report of metal level in the genetic form of Creutzfeldt-Jakob disease with E200K mutation, the most frequent subtype of gCJD world-wide. These findings are in controversy to the conclusion of Hesketh and colleagues (38) that the change in blood but also in brain manganese levels is possibly a universal change seen in all prion diseases.

Differences in copper levels between compared groups were not significant. This study presents for the first time the measurements of the copper isotope ratio $\left({ }^{65} \mathrm{Cu} /{ }^{63} \mathrm{Cu}\right)$ in brain tissue of CJD patients. On the basis of results, the mean ${ }^{65} \mathrm{Cu} /{ }^{63} \mathrm{Cu}$ ratios in the CJD group (0.486) and control group (0.487) were higher than the natural isotope ratio of 0.446 . The futher evaluation on differential utilization of $\mathrm{Cu}$ isotopes in brain of CJD patients is needed.

It could be interesting to compare also metal levels between sporadic CJD cases from Orava and other parts of Slovakia as well as controls from Orava and the rest of Slovakia. However this analysis could not be carried since there are not sporadic CJD cases from Orava region and at the same time Orava controls were not available for NRC PD.

Besides metal levels we focused also on the metal ratio (Mn/ $\mathrm{Cu}$ ) wishing to express a state of metal balance in the CNS of tested patients, since there is an evidence that a decreased copper concentration may decrease the prion protein stability and an elevated manganese level enables conformational changes in prion protein. The difference in the metal imbalance accrued with increasing metal rate $(\mathrm{Mn} / \mathrm{Cu})$ in brain tissue of CJD cases, in comparison to controls. Metal ratio $(\mathrm{Mn} / \mathrm{Cu})$ was increased in all tested CJD groups (both gCJD as well as SCJD) in comparison to controls. These results indicate that metal level may play a role in the CJD pathogenesis. It is experimentaly approved that if manganese replaces copper in cellular prion protein, it leads to conversion of protein into a changed secondary structure and to a protease resistance. It seems to be probable, that the observed metal imbalance in all tested CJD groups enables PrPsc formation. But the question, whether neurodegeneration and clinical symptoms of the disease develop because of the lack of the cellular prion protein with its antioxidant activity, or wheter this is a result of an accumulation and toxic effect of PrPsc, was still not answered.

The most evident metal imbalance was observed in gCJD from Orava. This imbalance was of statistical significance in comparison with $\mathrm{SCJD}(\mathrm{p}=0.027)$, but not in comparison with gCJD from extrafocal parts of Slovakia. Striking metal imbalance in both genetic tested groups suggests that more important event in the CJD pathogenesis than manganese elevation appears to be its consequence - the metal imbalance. Genetic CJD patients from extrafocal parts of Slovakia do not shown increased man- ganese levels; metal imbalance in this group was caused by the decreased copper. The reason for this, as well as an explanation why CJD may cause an elevation of manganese in brain tissue, is currently unknown.

Presented findings indicate that high manganese level and increased metal imbalance in gCJD from Orava are related to environmental condition in northern part of central Slovakia. Both gCJD groups involved the patients with the same genetic background, with CJD-specific E200K mutation of PRNP gene. Statistically significant differences in compared CJD as well as control groups observed mainly in investigated metal imbalance, strongly support the assumption that the environmental contamination in Orava may act as an exogenous co-factor and in coincidence with endogenous risk (the mutation E200K), participate in unique geographical clustering of gCJD.

In summary - manganese and copper concentrations and their imbalance were studied in the brain of SCJD, controls and for the first time also in gCJD patients. Genetic cases were either from the region with high environmental manganese contamination (they represented geographical cluster of gCJD) or from the less contaminated rest of the country. Results demonstrated significantly higher levels of manganese in clustering gCJD from the contaminated area when compared to all tested groups (sCJD, controls, gCJD outside of cluster). The observed $\mathrm{Mn} / \mathrm{Cu}$ ratio indicated significant metal disbalance in all CJD groups in comparison to controls. It was most pronounced in clustering gCJD cases. Presented results (1) indicate influence of $\mathrm{Mn} / \mathrm{Cu}$ disbalance in the pathogensis of both genetic and sporadic CJD, (2) provide the first data on elevated manganese level in the brain of gCJD patients and (3) support the role of environmental Mn contamination as an exogenous co-factor and which in coincidence with the endogenous risk (the mutation E200K) participates in accumulation of gCJD patients to the geographical cluster.

\section{Acknowledgements}

This research was funded by Science and Technology assistance Agency under the contract No. APVT-21-019004 and by the grant through the EEA FM and the Norwegian FM (Project SK0020).

\section{REFERENCES}

1. Büeler H, Fischer M, Lang Y, Bluethmann H, Lipp HP, DeArmond SJ, et al. Normal development and behaviour of mice lacking the neuronal cell-surface PrP protein. Nature. 1992 Apr 16;356(6370):577-82.

2. Prusiner SB, Bolton DC, Groth DF, Bowman KA, Cochran SP, McKinley MP. Further purification and characterization of scrapie prions. Biochemistry. 1982 Dec 21;21(26):6942-50.

3. Prusiner SB, McKinley MP, Bolton DC et al. Prions: methods for assay, purification and characterization. In: Maramorosch K, Koprowski H, editors. Methods in virology. New York: Academic press; 1984. p. 293-345.

4. Prusiner SB. Molecular biology of prion diseases. Science. 1991 Jun 14;252(5012):1515-22.

5. Brown DR, Schmidt B, Groschup MH, Kretzschmar HA. Prion protein expression in muscle cells and toxicity of a prion protein fragment. Eur J Cell Biol. 1998 Jan;75(1):29-37.

6. Guentchev M, Voigtländer T, Haberler C, Groschup MH, Budka H. Evidence for oxidative stress in experimental prion disease. Neurobiol Dis. 2000 Aug;7(4):270-3.

7. Brown DR, Qin K, Herms JW, Madlung A, Manson J, Strome R, et al The cellular prion protein binds copper in vivo. Nature. 1997 Dec 1825;390(6661):684-7.

8. Brown DR, Wong BS, Hafiz F, Clive C, Haswell SJ, Jones IM. Normal prion protein has an activity like that of superoxide dismutase. Biochem 
J. 1999 Nov 15;344 Pt 1:1-5. Erratum in: Biochem J. 2000 Feb 1;345 Pt 3:767.

9. Brown DR, Hafiz F, Glasssmith LL, Wong BS, Jones IM, Clive C, et al. Consequences of manganese replacement of copper for prion protein function and proteinase resistance. EMBO J. 2000 Mar 15;19(6):1180-6.

10. Wong BS, Wang H, Brown DR, Jones IM. Selective oxidation of methionine residues in prion proteins. Biochem Biophys Res Commun. 1999 Jun 7;259(2):352-5.

11. Pan KM, Baldwin M, Nguyen J, Gasset M, Serban A, Groth D, et al. Conversion of alpha-helices into beta-sheets features in the formation of the scrapie prion proteins. Proc Natl Acad Sci U S A. 1993 Dec 1;90(23):10962-6.

12. Stahl N, Baldwin MA, Teplow DB, Hood L, Gibson BW, Burlingame $\mathrm{AL}$, et al. Structural studies of the scrapie prion protein using mass spectrometry and amino acid sequencing. Biochemistry. 1993 Mar 2;32(8):1991-2002.

13. Giese A, Levin J, Bertsch U, Kretzschmar H. Effect of metal ions on de novo aggregation of full-length prion protein. Biochem Biophys Res Commun. 2004 Aug 6;320(4):1240-6.

14. Tsenkova RN, Iordanova IK, Toyoda K, Brown DR. Prion protein fate governed by metal binding. Biochem Biophys Res Commun. 2004 Dec 17;325(3):1005-12.

15. Mitrová E, Belay G. Creutzfeldt-Jakob disease with E200K mutation in Slovakia: characterization and development. Acta Virol. 2002;46(1):31-9.

16. Büchl A, Hawkesworth CJ, Ragnarsdottir KV, Brown DR. Re-partitioning of $\mathrm{Cu}$ and $\mathrm{Zn}$ isotopes by modified protein expression. Geochem Trans. 2008 Oct 10;9:11.

17. Brazier MW, Volitakis I, Kvasnicka M, White AR, Underwood JR, Green $\mathrm{JE}$, et al. Manganese chelation therapy extends survival in a mouse model of M1000 prion disease. J Neurochem. 2010 Jul;114(2):440-51.

18. Thackray AM, Knight R, Haswell SJ, Bujdoso R, Brown DR. Metal imbalance and compromised antioxidant function are early changes in prion disease. Biochem J. 2002 Feb 15;362(Pt 1):253-8.

19. Barceloux DG. Manganese. J Toxicol Clin Toxicol. 1999;37(2):293-307.

20. Markesbery WR, Ehmann WD, Hossain TI, Alauddin M. Brain manganese concentrations in human aging and Alzheimer's disease. Neurotoxicology. 1984;5(1):49-57.

21. Tanaka S, Lieben J. Manganese poisoning and exposure in Pennsylvania. Arch Environ Health. 1969 Nov;19(5):674-84.

22. Mitrová E. Some new aspects of CJD epidemiology in Slovakia. Eur J Epidemiol. 1991 Sep;7(5):439-49.

23. Wong BS, Chen SG, Colucci M, Xie Z, Pan T, Liu T, et al. Aberrant metal binding by prion protein in human prion disease. J Neurochem. $2001 \mathrm{Sep} ; 78(6): 1400-8$.

24. Ursinyova M, Vanova R, Palusova O. Monitoring of dust deposition and its components in ambient air in Slovakia. AHEM. 1992;(2):1-21. (In Slovak.)
25. Pukancikova K. Air pollution in the Slovak Republic 2003. Bratislava: Ministry of Environment of the Slovak Republic, Slovak Hydrometeorological Institute; 2004. (In Slovak.)

26. Purdey M. Ecosystems supporting clusters of sporadic TSEs demonstrate excesses of the radical-generating divalent cation manganese and deficiencies of antioxidant co factors $\mathrm{Cu}, \mathrm{Se}, \mathrm{Fe}, \mathrm{Zn}$. Does a foreign cation substitution at prion protein's Cu domain initiate TSE? Med Hypotheses. 2000 Feb;54(2):278-306.

27. Ranostajova K. Analyses of metal levels in hair of children in Dolny Kubin and Oravska Lesna, 1983/1987/1995. Dolný Kubín: SZU Dolný Kubín; 1995 (In Slovak.)

28. Masánová V, Mitrova E, Ursinyova M, Uhnakova I, Slivarichova D. Manganese and copper imbalance in the food chain constituents in relation to Creutzfeldt-Jakob disease. Int J Environ Health Res. 2007 Dec;17(6):419-28.

29. Barbeau A. Manganese and extrapyramidal disorders (a critical review and tribute to Dr. George C. Cotzias). Neurotoxicology. 1984;5(1):13-35.

30. Bastian F. CJD and other transmissible spongiform encephalopathies. St Louis: Mosby Year Book; 1991.

31. Banta RG, Markesbery WR. Elevated manganese levels associated with dementia and extrapyramidal signs. Neurology. 1977 Mar;27(3):213-6.

32. Abdel-Naby S, Hassanein M. Neuropsychiatric manifestations of chronic manganese poisoning. J Neurol Neurosurg Psychiatry. 1965 Jun;28:282-8.

33. Aschner M, Aschner JL. Manganese neurotoxicity: cellular effects and blood-brain barrier transport. Neurosci Biobehav Rev. 1991;15(3):333-40.

34. Mitrová E. Analytical epidemiology and risk factors of CJD. In: Court LA, Dormont D, Kingsbury DT, editors. Uncoventional virus diseases of the central nervous system. Paris: Masson; 1986. p. 19-28.

35. Oberdoester G, Cherian G. Manganese. In: Biological monitoring of toxic metals. New York: Plenum; 1988. p. 283-301.

36. Heilig E, Molina R, Donaghey T, Brain JD, Wessling-Resnick M. Pharmacokinetics of pulmonary manganese absorption: evidence for increased susceptibility to manganese loading in iron-deficient rats. Am J Physiol Lung Cell Mol Physiol. 2005 May;288(5):L887-93.

37. Legleiter LR, Liu HC, Lloyd KE, Hansen SL, Fry RS, Spears JW. Exposure to low dietary copper or low copper coupled with high dietary manganese for one year does not alter brain prion protein characteristics in the mature cow. J Anim Sci. 2007 Nov;85(11):2895-903.

38. Hesketh S, Sassoon J, Knight R, Brown DR. Elevated manganese levels in blood and CNS in human prion disease. Mol Cell Neurosci. 2008 Mar;37(3):590-8. 